\title{
In vivo Hemostatic Activity of Jatropha mollissima: A Triple-Blinded, Randomized, Controlled Trial in an Animal Model
}

\author{
Maria Vitoria Oliveira Dantas ${ }^{1}$ Paula Lima Nogueira ${ }^{1} \quad$ Filipe de Oliveira Lima ${ }^{1}$ \\ Denis Candeia Pereira Oliveira' ${ }^{1}$ Emanuelly Nara Severiano Gomes ${ }^{1}$ \\ José Filipe Bacalhau Rodrigues ${ }^{2}$ Solomon Kweku Sagoe Amoah ${ }^{2}$ Rosana Araújo Rosendo ${ }^{3}$ \\ Elizandra Silva da Penha ${ }^{3}$ Antonio Flávio Medeiros Dantas ${ }^{4}$ Marcus Vinícius Lia Fook ${ }^{2}$ \\ Rogério Lacerda-Santos ${ }^{5, \bullet}$ Luanna Abílio Diniz Melquiades de Medeiros ${ }^{3}$
}

\footnotetext{
${ }^{1}$ Federal University of Campina Grande, Patos, Paraíba, Brazil

${ }^{2}$ Academic Unit of Materials Engineering, Federal University of

Campina Grande, Campina Grande, Paraíba, Brazil

${ }^{3}$ Academic Unit of Biological Sciences - Dentistry, Federal University of Campina Grande, Patos, Paraíba, Brazil

${ }^{4}$ Academic Unit of Veterinary Medicine, Federal University of Campina Grande, Patos, Paraíba, Brazil

${ }^{5}$ Department of Orthodontics, Faculty of Dentistry, Federal University of Juiz de Fora, Governador Valadares, Minas Gerais, Brazil
}

Eur J Dent 2021;15:741-745.

\begin{abstract}
Address for correspondence Rogério Lacerda-Santos, DDS, MSD, PhD, Department of Orthodontics, Faculty of Dentistry, Federal University of Juiz de Fora, Avenue Doutor Raimundo Monteiro Rezende, n.330, Centro, CEP 35010-177, Governador Valadares, Minas Gerais, Brazil (e-mail: lacerdaorto@hotmail.com; lacerdaorto@gmail.com).
\end{abstract}

\begin{abstract}
Keywords

- hemostasis

- phytotherapy

- biomaterial

Objective The objective of this study was to evaluate the hemostatic activity of the sap from Jatropha mollissima (Pohl) Baill. in rats.

Materials and Methods Twenty-four Wistar rats were randomized into four groups $(n=6)$ : the JM25 and JM40 groups were treated with ethanolic extract from the sap of J. mollissima, in a concentration of 25 and $40 \mathrm{mg} \cdot \mathrm{mL}^{1}$, respectively; the $\mathrm{MO}$ group was treated with Monsel's solution and the control group SC with a $0.9 \%$ sodium chloride solution.

Statistical Analysis Data were submitted to the Kurskal-Wallis' test, followed by Dunn's post hoc $(p<0.05)$.

Results There was a significant reduction in the bleeding time of the group from the JM25 extract ( $p=0.001)$ when compared with MO and SC. There were no statistically significant differences between groups JM25 and JM40 ( $p>0.05)$. The JM25 group did not present rebleeding, a result significantly different from the MO group $(p=0.001)$. Monsel's solution showed significant bleeding, six times greater than the control group SC.

Conclusion The J. mollissima extract, in the concentration of $25 \mathrm{mg} \cdot \mathrm{mL}^{1}$, showed the highest hemostatic efficiency and was found to be a promising biomaterial for the elaboration of a hemostatic product.
\end{abstract}

published online

August 24, 2021
DOI https://doi.org/

10.1055/s-0041-1729677

ISSN $1305-7456$
(C) 2021. European Journal of Dentistry.

This is an open access article published by Thieme under the terms of the Creative Commons Attribution-NonDerivative-NonCommercial-License, permitting copying and reproduction so long as the original work is given appropriate credit. Contents may not be used for commercial purposes, or adapted, remixed, transformed or built upon. (https://creativecommons.org/licenses/by-nc-nd/4.0/).

Thieme Medical and Scientific Publishers Pvt. Ltd. A-12, 2nd Floor, Sector 2, Noida-201301 UP, India 


\section{Introduction}

Hemostasis is a natural process that takes place after a lesion, in which blood loss is hampered. ${ }^{1}$

The basic treatment for bleeding wounds consists the application of pressure using gauze, in an effort to stop the blood flow, which may also need the use of suture materials. $^{2}$ As a result, hemostasis will occur in minutes, with the exception of cases involving serious wounds or bleeding disorders, in which hemostatic materials can be used to induce or accelerate coagulation. ${ }^{1}$ The hemostatic materials should be able to curb the bleeding rapidly, be biocompatible and if possible biodegradable. ${ }^{2}$

Biomaterials have contributed to the health research field, especially in association with phytotherapy, ${ }^{3}$ employing different medicinal plants with known or unknown biological activities. ${ }^{4,5}$ As a result, quality control to ascertain the safety of these phytotherapy is necessary to guarantee safety against toxicity. ${ }^{6}$

The specie Jatropha mollissima (Pohl) Baill., popularly known as "pinhão-bravo" is a plant that is present in the entire Brazilian semi-arid regions and part of the caatinga vegetation $^{7,8}$ with different medicinal applications. ${ }^{9,10}$ It has antiophidic properties, acting against the effects caused by snake bites, such as the formation of edemas and local hemorrhage, and it possesses antibacterial activity against pathogens such as Staphylococcus aureus, Salmonella typhi, Salmonella typhimurium, and Listeria monocytogenes. ${ }^{11,12}$

However, it is popularly used as a healing plant, with its latex and sap being used to treat hemorrhages, cuts, and injuries, ${ }^{7,13}$ despite the lack of studies that consolidates its hemostatic and healing action. ${ }^{13,14}$

Considering the above, the objective of this study was to evaluate in vivo the hemostatic action of the J. mollissima (Pohl) Baill. sap, aiming to propose a hemostatic product for medical-odontological use.

\section{Materials and Methods}

\section{Sample Size}

This study was approved by the Animals Research Ethics Committee of the CSTR: Centro de Saúde e Tecnologia Rural (Center of Health and Rural Technology) UFCG: Universidade Federal de Campina Grande (Federal University of Campina Grande) CSTR/UFCG, under approval No.06/2020. For a 12 -second standard deviation and a minimal intergroup difference of 34 seconds for the time of bleeding, a sample of five animals was needed to reach an $85 \%$ statistical power, with 0.05 alpha. The size of the sample was similar to that used in the previous studies. ${ }^{15,16}$

\section{Animal Selection}

This research used 24 male adult Wistar rats of around $250 \mathrm{~g}$, from the UFCG vivarium. The animals were randomized into four groups ( $n=6)$ : JM25 and JM40, both treated with the ethanolic extract of the J. mollissima sap, in concentrations of 25 and $40 \mathrm{mg} \cdot \mathrm{mL}^{1}$, respectively; the MO group was treated with Monsel's solution (Lenzafarm, Minas Gerais, Brazil), and the control group SC was treated with a $0.9 \%$ sodium chloride $(\mathrm{NaCl})$ solution (Sorimax, Farmax Ltd., Minas Gerais, Brazil).

The animals were placed in EB 273C (Insight Ltd, Sao Paulo, Brazil) vivarium cabinets, with temperature control at $23 \pm 1^{\circ} \mathrm{C}, 41 \%$ humidity, and were fed, during the entire period of the experiment, a solid diet of animal ration and water "ad libitum." "17-19

\section{Biomaterial}

The J. mollissima sap was collected in the city of Boa Vista, Paraíba, Brazil. Three incisions were made on the stem of the plant and the dripping sap was collected. Later, it was filtered through a 100-mesh filter and stored in disposable $20 \mathrm{~mL}$ syringes (Descarpack Ltd., Sao Paulo, Brazil), in which they were transported to the Northeast Laboratory for the Evaluation and Development of Biomaterials-Laboratório de Avaliação e Desenvolvimento de Biomateriais do Nordeste (Northeast Laboratory for the Evaluation and Development of Biomaterials) CERTBIO/UFCG, whereupon they were transferred to glass recipients, identified, and stored in freezers at $4^{\circ} \mathrm{C}$, protected from light throughout the process. ${ }^{13}$

The ethanolic extract of the sap was obtained through a preparation with $1: 1$ ratio of sap to solvent, that is, $1 \mathrm{~L}$ of sap to $1 \mathrm{~L}$ of ethanol. The mixture was left to rest at room temperature and protected from light for 3 days, so the substances could be extracted. After this period, the extract was filtered through a vacuum filtration and concentrated using a rotary evaporator (Heidolph Laborota 4000) until the ethanol was entirely eliminated. Subsequently, it was frozen in the ultra-low temperature freezer for 48 hours and submitted to a lyophilization process, to completely remove the water via sublimation. The result was a dry, reddish orange extract.

Finally, the crude ethanolic extract from the J. mollissima sap was diluted in a saline solution $\mathrm{NaCl} 0.9 \%$, to obtain the concentrations of 25 and $40 \mathrm{mg} \cdot \mathrm{mL}^{1}$.

\section{Surgical Procedure}

For the surgical intervention, the animals were anesthetized using an intraperitoneal injection ${ }^{20}$ of a mixture of $10 \%$ ketamine hydrochloride (Vetnil, Vetecia, Sao Paulo, Brazil) (75 mg/kg), 2\% xylazine hydrochloride (União Química, Sao Paulo, Brazil) $(10 \mathrm{mg} / \mathrm{kg})$, and $0.15 \mathrm{~mL}$ of $0.9 \% \mathrm{NaCl}$.

Later, the surgical area was cleaned using a $2 \%$ chlorhexidine solution (Riohex, Rioquímica Ltd., Sao Paulo, Brazil), and a distal segment of $10 \mathrm{~mm}$ (-Fig. 1) was amputated from the tip of the tail of the rat, in a crosscut with a size-15 scalpel blade. ${ }^{21,22}$

Then, $1 \mathrm{~mL}$ of the solution was applied using a 1-mL insulin syringe attached to a 25/7 needle. The application lasted

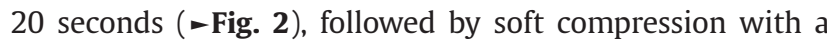
sterile gauze for 1 minute. A chronometer was used to measure how long it took for hemostasis to be attained. The time count started at the moment of incision and stopped at the moment the bleeding at the site stopped completely. To determine the amount of blood lost, each sterile gauze was weighted before and after the procedure using a precision laboratory scale (Shimadzu AY220; Shimadzu, Sao Paulo, Brazil), and the difference in grams, after subtracting the weight of 


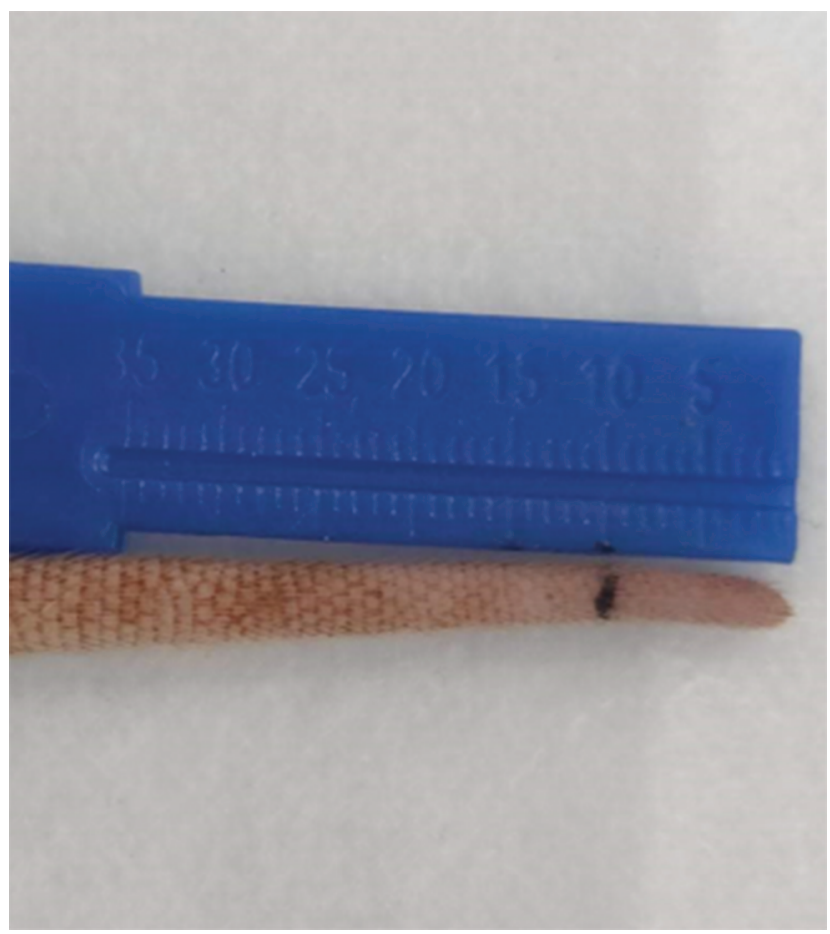

Fig. 1 Marking (10 mm), with the aid of a sterile ruler with millimeters, for the amputation of the tip of the tail of the animal.

the corresponding solution applied, was used as a measure for the amount of blood lost. After the bleeding had stopped, each animal was monitored for 20 minutes, to detect any cases of rebleeding. The evaluation of hemostatic analyzes were performed by previously calibrated researchers (kappa $=0.90$ ).

After this procedure, the animals were sedated using intraperitoneal ketamine hydrochloride $(100 \mathrm{mg} / \mathrm{kg}$ ) and xylazine hydrochloride $(10 \mathrm{mg} / \mathrm{kg}$ ). Then, the rats were euthanized, using the cervical dislocation technique ${ }^{23}$ recommended by the American Veterinary Medical Association Guidelines for the Euthanasia of Animals. ${ }^{24}$

This study was randomized and triple-blind; each experimental material used in the animals was inserted in groups I to $I V,{ }^{25}$ in such a way that the examiner and the statistical evaluator had no knowledge of the materials used.

\section{Statistical Analysis}

Data were analyzed using the software GraphPad Prism, version 5.0 (San Diego, California, United States). The statistical method was chosen based on the model of distribution and variance of data, which was determined using the Kolmogorov-Smirnov's and Levene's tests, respectively. The results of the hemostatic analysis did not have a normal distribution, and as a result, they were submitted to the nonparametric Kruskal-Wallis' test, followed by the Dunn's test to determine the differences between the groups $(p<0.05)$.

\section{Results}

The bleeding time was longer and similar for the Monsel's solution group-MO (2 minutes and 74 seconds) and for the saline control group-SC (2 minutes and 59 seconds).

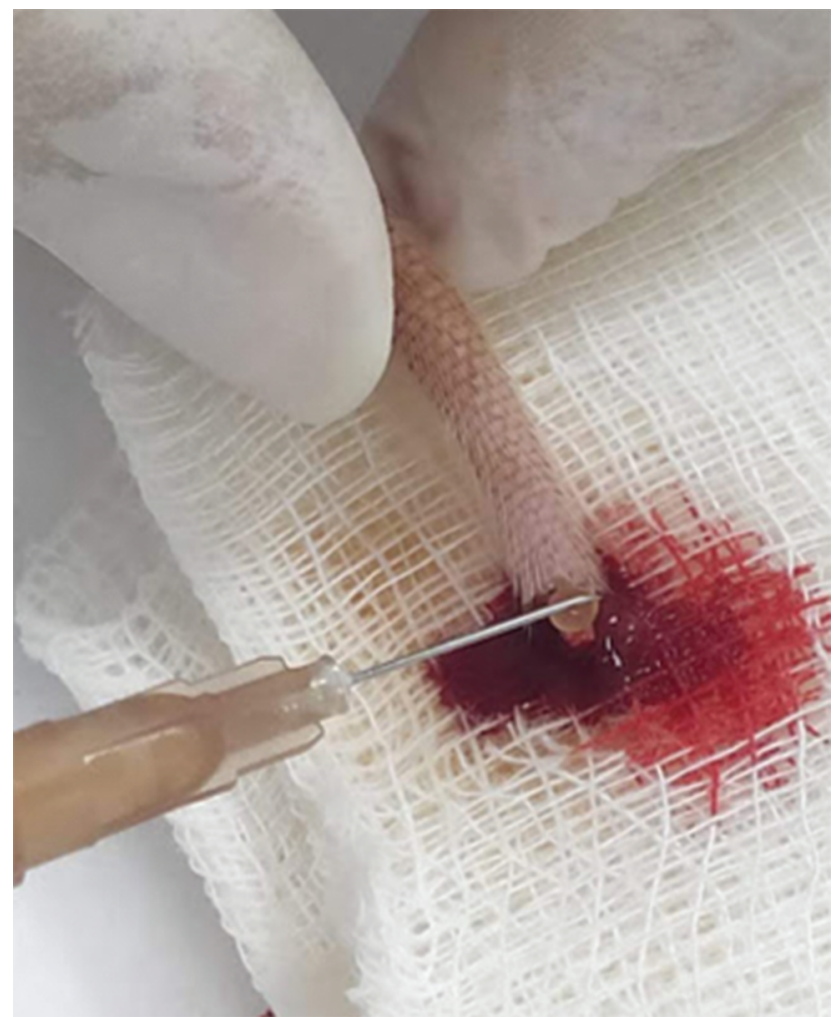

Fig. 2 Application of the ethanolic extract from the Jatropha mollissima extract in a $25 \mathrm{mg} \cdot \mathrm{mL}^{1}$ concentration.

The duration of the bleeding was significantly lower in the hemostatic group that used the $25 \mathrm{mg} \cdot \mathrm{mL}^{1} \mathrm{~J}$. mollissima extract-JM25 ( $p=0.001$ ), when compared with MO and SC. There were no statistical differences between the $40 \mathrm{mg} \cdot \mathrm{mL}^{1}$ J. mollissima extract-JM40-and the others.

The rebleeding lasted longer in the MO group (1 minute and 7 seconds), but there were no statistical differences when compared with JM40 and control group SC ( $p>0.05)$. The JM25 group was the only one that showed no rebleeding after the first hemostasis, with a statistically significant difference from the MO group ( $p=0.001$ ).

The weight of the blood up to the first hemostasis was similar for the JM25 group and for the control SC, but significantly lower than the MO group $(p=0.002)$. The MO group displayed six times more bleeding than the SC control group (-Table 1).

\section{Discussion}

The pharmacological properties and chemical composition of the genus Jatropha have shown correlations between secondary metabolites and the different bioactivities, such as the hemostatic, healing, and antimicrobial action, especially in the case of Jatropha curcas and Jatropha gossypiifolia, J. mollissima is still a seldom-studied species. ${ }^{26}$

The latex/sap of some Jatropha species has been described as hemostatic and healing when applied topically on injuries. ${ }^{27,28}$ Hemostasis is a process in which the blood flow diminishes, and clots are formed to avoid further blood loss. It happens in two stages: the primary stage, in which blood 
Table 1 Hemostatic analysis of the amount of blood, time of bleeding, and rebleeding, for the different groups evaluated

\begin{tabular}{|c|c|c|c|c|c|}
\hline \multirow[t]{2}{*}{ Analysis } & \multicolumn{4}{|l|}{ Groups } & \multirow[t]{2}{*}{$p$-Value } \\
\hline & JM25 & JM40 & MO & SC & \\
\hline Time of bleeding (s) & $95.66(5.46)^{A}$ & $121.01(12.26)^{\mathrm{AB}}$ & $164.50(26.33)^{\mathrm{B}}$ & $155.66(22.93)^{\mathrm{B}}$ & 0.001 \\
\hline Time of rebleeding (s) & $0.0(0.0)^{\mathrm{A}}$ & $17.16(4.44)^{\mathrm{AB}}$ & $64.66(28.04)^{\mathrm{B}}$ & $16.83(8.51)^{\mathrm{AB}}$ & 0.001 \\
\hline $\begin{array}{l}\text { Weight of the blood } \\
\text { (g) }\end{array}$ & $0.13(0.03)^{A}$ & $0.27(0.13)^{A B}$ & $0.78(0.33)^{\mathrm{B}}$ & $0.12(0.07)^{A}$ & 0.002 \\
\hline
\end{tabular}

Abbreviations: JM25, Jatropha mollissima $25 \mathrm{mg} \cdot \mathrm{mL}^{1}$; JM40, Jatropha mollissima $40 \mathrm{mg} \cdot \mathrm{mL}^{1}$; MO, Monsel's solution; SC, sodium chloride $0.9 \%$.

Note: The values represent the mean values and the standard deviation for the six animals evaluated in each group, Different superscript capital letters $(A, B)$ expressed statistically significant differences in the lines.

aMeans followed by distinct letters express significant differences $(p<0.05)$, according to the Kruskal-Wallis' nonparametric test, followed by Dunn's multiple comparisons test.

vessels contract and the platelet plug is formed, and the secondary stage, where the plug is reinforced with a fibrin strands to maintain the clot in its place through the activation of the coagulation cascade. ${ }^{1}$

Therefore, the topic hemostasis is established as a process that works with the objective of stopping the bleeding of damaged health vessels, to accelerate one or all stages of hemostasis and stop the hemorrhage. ${ }^{29}$

The procoagulation activity of the J. gossypiifolia latex was verified in different studies ${ }^{30,31}$ that showed the protein precipitation as its mechanism of action, which induced coagulation and later hemostasis. The extract significantly diminished the time of in vitro human blood coagulation in healthy individuals treated with a drop of latex at the site of the lesion. ${ }^{31}$

In this study, the hemostatic action of the J. mollissima sap was evaluated using the technique of amputating the extremity of the tail of rats, which is a standard and reliable practice to analyze the hemostatic properties of biomaterials. $^{32}$ The JM25 group, to which an extract of a concentration of $25 \mathrm{mg} \cdot \mathrm{mL}^{1}$ was applied, presented a significantly higher diminution ( $p=0.001)$ in the time of bleeding, which was 1 minute and 35 seconds, when compared with controls SC and MO, in which bleeding lasted 2 minutes and 35 seconds and 2 minutes and 44 seconds, respectively. Although the $25 \mathrm{mg} \cdot \mathrm{mL}^{1}$ concentration led to a notably shorter time of bleeding than the $40 \mathrm{mg} \cdot \mathrm{mL}^{1}$ concentration, there was no significant difference between these groups. This study suggests that, at $40 \mathrm{mg} \cdot \mathrm{mL}^{1}$, the sap may be provoking toxic side effects that are stronger than its hemostatic powers at the injured site, which were not presented in the $25 \mathrm{mg} \cdot \mathrm{mL}^{1}(\mathrm{w} / \mathrm{v})$ concentration.

These results are in accordance with studies that investigated the therapeutic properties of the J. mollissima latex and found phenolic compounds, ${ }^{11,13,27,33}$ saponins, ${ }^{13,27,33}$ tannins, flavonoids, ${ }^{11,13,27,33}$ coumarins, alkaloids, and steroids. ${ }^{11}$ The tannins, expressively found in the latex, have shown important antimicrobial, anti-inflammatory, and healing powers, being capable of controlling bleeding through their astringent effect over the contraction of damaged vessels and tissues, precipitating the proteins of blood and favoring hemostasis. ${ }^{13,34,35}$

In this study, the animals were observed for 20 minutes after the initial hemostasis. Only the JM25 group, with a concentration of $25 \mathrm{mg} \cdot \mathrm{mL}^{1}$ of the extract, did not present rebleeding, with a significant difference from the MO group ( $p=0.001$ ), which presented the longest rebleeding, with
1 minute and 4 seconds. Monsel's solution has ferric subsulfate, sulfuric acid, and nitric acid in its composition, and has been used as a topical hemostatic in small surgical, dermatological, gynecological, and odontological procedures ${ }^{36}$; when it gets in touch with the bleeding injury, it provokes a reaction triggered by the high $\mathrm{pH}$ of the ferric subsulfate, which denatures and agglutinates the blood proteins, stimulating the obstruction of the blood vessels by blood clots. ${ }^{37}$

However, in spite of the benefits from the ferric subsulfate, the MO group presented the longest time of rebleeding ( 1 minute and 4 seconds) when compared with the SC and JM40, and a significant amount of rebleeding, six times higher than the SC control group. These results are in accordance with studies which showed that Monsel's solution is not sufficiently efficient, since it has toxic agents from the sulfate group in its composition, which promote several significant side effects, such as erythema, postinflammatory hyperpigmentation, and increased risk of infection. ${ }^{36,38}$

According to the results, the ethanolic extract from the $J$. mollissima (Pohl) Baill. sap in a $25 \mathrm{mg} \cdot \mathrm{mL}^{1}$ concentration was found to be a promising biomaterial, presenting significant hemorrhage action with therapeutic potential, to be used in the clinical treatment of local hemorrhage. Clinical trials in humans ${ }^{39}$ could be used to confirm the hemostatic potential of the J. mollissima sap showed in this study, in addition to verifying whether smaller concentration could maintain the same hemostatic power and its mechanisms.

\section{Conclusion}

The J. mollissima sap extract:

- Is an effective biomaterial to elaborate a hemostatic material for clinical use;

- Has a hemostatic effect on the time of bleeding and rebleeding;

- At $25 \mathrm{mg} \cdot \mathrm{mL}^{1}$, the hemostatic efficacy is higher.

\section{Conflict of Interest}

None declared.

\section{References}

1 Panwar V, Sharma A, Thomas J, et al. In-vitro and in-vivo evaluation of biocompatible and biodegradable calcium-modified 
carboxymethyl starch as a topical hemostat. Materialia (Oxf) 2019;7:100373

2 Wiegand C, Abel M, Hipler UC, et al. Hemostatic wound dressings: predicting their effects by in vitro tests. J Biomater Appl 2019;33(9):1285-1297

3 Rosi F, Perale G, Masi M. Introduction: chemical engineering and medicine. In: Controlled Drug Delivery Systems. Springer Nature, Switzerland; 2016, 1 Edition: 1-7

4 Barbosa HM, Albino AM, Cavalcante FS, Lima RA. Phychochemical approach of secondary metabolites in Sola num acanthodes (SOLANACEAE) HOOK. South Am J Basic Educ Tech 2017;4(1):30-41

5 Bruning MC, Mosegui GB, Vianna CM. [The use of phytotherapy and medicinal plants in primary healthcare units in the cities of Cascavel and Foz do Iguaçu - Paraná: the viewpoint of health professionals]. Cien Saude Colet 2012;17(10):2675-2685

6 Silva NC, Vitor A, Bessa HH, Barros RM. Use of medicinal plants and herbal medicines for health. Única Cadernos Acadêmicos 2017;3(1):10-14

7 Dias WLF, Junior EPV, Oliveira MDDA, et al. Cytogenotoxic effect, phytochemical screening and antioxidant potential of Jatropha mollissima (Pohl) Baill leaves. S Afr J Bot 2019;123:30-35

8 Soares AFB, Silva JN. Study and monitoring of the generation of technologies using gender plants Jatropha. Cadernos de Prospecção 2018;12(2):413

9 Trindade MJS, Lameira OA. Species from the Euphorbiaceae family used for medicinal purposes in Brazil. Rev Cuba Plantas Med 2014;19(4):292-309

10 Sun L, Li M, Ma C, Li P. Preparation and evaluation of Jatropha curcas based catalyst and functionalized blend components for low sulfur diesel fuel. Fuel 2017;206:27-33

11 Braquehais ID, Vasconcelos FR, Ribeiro ARC, et al. Toxicological, antibacterial, and phytochemical preliminary study of the ethanolic extract of Jatropha mollissima (Pohl) Baill (pinhão-bravo, Euphorbiaceae) leaves, collected in Tauá, Ceará, Northeastern Brazil. Rev Bras Plantas Med 2016;18(2:Suppl 1):582-587

12 Souza DD, Cavalcanti NB. Biometry of fruits and seeds of Jatropha mollissima (Pohl) Baill. (Euphorbiaceae) Acta Biol Catarinense 2019;6(2):115-122

13 Neto RFQ Júnior HNA, Freitas CIA, et al. The Jatropha mollissima (Pohl) Baill: chemical and pharmacological activities of the latex and its extracts. Semin Cienc Agrar 2020;40(6):2613-2624

14 Pimentel LA, Riet-Correa B, Dantas AF, Medeiros RM, Riet-Correa F. Poisoning by Jatropha ribifolia in goats. Toxicon 2012;59(5):587-591

15 Penha ESD, Lacerda-Santos R, Carvalho MGF, Oliveira PT. Effect of Chenopodium ambrosioides on the healing process of the in vivo bone tissue. Microsc Res Tech 2017;80(11):1167-1173

16 Penha ESD, Lacerda-Santos R, de Medeiros LADM, et al. Effect of chitosan and Dysphania ambrosioides on the bone regeneration process: a randomized controlled trial in an animal model. Microsc Res Tech 2020;83(10):1208-1216

17 Lacerda-Santos R, de Meneses IH, Sampaio GA, Pithon MM, Alves PM. Effect of degree of conversion on in vivo biocompatibility of flowable resin used for bioprotection of mini-implants. Angle Orthod 2016;86(1):157-163

18 Meneses IHC, Sampaio GAM, Carvalho FG, et al. In vivo biocompatibility, mechanical, and antibacterial properties of cements modified with propolis in different concentrations. Eur J Dent 2020;14(1):77-84

19 Mesquita JA, Lacerda-Santos R, Sampaio GAM, Godoy GP, Nonaka CFW, Alves PM. Evaluation in vivo of biocompatibility of differents resin-modified cements for bonding orthodontic bands. An Acad Bras Cienc 2017;89(3(Suppl):2433-2443

20 Lacerda-Santos R, Roberto BMS, de Siqueira Nunes B, Carvalho FG, Dos Santos A, Dantas AFM. Histological analysis of biocompatibility of different surgical adhesives in subcutaneous tissue. Microsc Res Tech 2019;82(7):1184-1190
21 Lacerda-Santos R, Lima ABL, Penha ESD, et al. In vivo biocompatibility of silicon dioxide nanofilm used as antimicrobial agent on acrylic surface. An Acad Bras Cienc 2020;92(1):e20181120

22 Sampaio GM, de Meneses IH, de Carvalho FG, et al. Antimicrobial, mechanical and biocompatibility analysis of chlorhexidine digluconate-modified cements. J Clin Exp Dent 2020;12(2):e178-e186

23 Lacerda-Santos R, Sampaio GA, Moura MdeF, et al. Effect of different concentrations of chlorhexidine in glass-ionomer cements on in vivo biocompatibility. J Adhes Dent 2016;18(4):325-330

24 Leary S, Underwood W, Anthony R, et al. AVMA guidelines for the euthanasia of animals, 2020 edition, Schaumburg: American Veterinary Medical Association, 2020:1-121

25 Sampaio GAM, Lacerda-Santos R, Cavalcanti YW, Vieira GHA, Nonaka CFW, Alves PM. Biocompatibility of ionomeric cements modified by red propolis: a morphological and immunohistochemical analysis. J Adhes Dent 2020;22(5):515-522

26 Cavalcante NB, Diego da Conceição Santos A, Guedes da Silva Almeida JR. The genus Jatropha (Euphorbiaceae): a review on secondary chemical metabolites and biological aspects. Chem Biol Interact 2020;318(1):108976

27 Badgujar SB. Evaluation of hemostatic activity of latex from three Euphorbiaceae species. J Ethnopharmacol 2014;151(1):733-739

28 Uday P, Achar RR, Bhat RP, et al. Laticiferous plant proteases in wound care. Int J Pharm Pharm Sci 2015;7(Supple1):44-49

29 Khoshmohabat H, Paydar S, Kazemi HM, Dalfardi B. Overview of agents used for emergency hemostasis. Trauma Mon 2016;21(1):e26023

30 Apu AS, Ireen K, Bhuyan SH, Matin M, Hossain MF, Rizwan F. Evaluation of analgesic, neuropharmacological and anti-diarrheal potential of Jatropha gossypifolia (Linn.) leaves in mice. J Med Sci 2012;12(8):274-279

31 Oduola T, Adeosun GO, Oduola TA, Avwioro GO, Oyeniyi MA. Mechanism of action of Jatropha gossypifolia stem latex as a haemostatic agent. Eur J Gen Med 2005;2(4):140-143

32 Ebrahimi F, Mahmoudi J, Torbati M, Karimi P, Valizadeh H. Hemostatic activity of aqueous extract of Myrtus communis L. leaf in topical formulation: in vivo and in vitro evaluations. J Ethnopharmacol 2020;249(1):112398

33 Pereira B, Brazón J, Rincón M, Vonasek E. Browplasminin, a condensed tannin with anti-plasmin activity isolated from an aqueous extract of Brownea grandiceps Jacq. flowers. J Ethnopharmacol 2017;198(1):282-290

34 Martelli A, Andrade TAM, Santos GMT. Perspectives in the use of herbal medicines in tissue healing: systematic review. Arch Health Invest 2018;7(8):344-350

35 Soltani R, Haghighat A, Fanaei M, Asghari G. Evaluation of the effect of green tea extract on the prevention of gingival bleeding after posterior mandibular teeth extraction: a randomized controlled trial. Evid Based Complement Alternat Med 2014;2014:857651

36 Byun J-Y, Lee S, Lee JI, Yoon H-Y. Comparison of hemostatic efficacy and cytotoxicity of three ferric subsulfate-and chitosan-based styptics in different formulations using a rat tail bleeding model. Korean J Vet Res 2018;58(3):119-124

37 Tompeck AJ, Gajdhar AUR, Dowling M, et al. A comprehensive review of topical hemostatic agents: the good, the bad, and the novel. J Trauma Acute Care Surg 2020;88(1):e1-e21

38 Abzaeva KA, Zelenkov LE. Modern topical hemostatic agents and unique representatives of their new generation. Russ Chem Bull 2015;64:1233-1239

39 Amer MZ, Mourad SI, Salem AS, Abdelfadil E. Correlation between international normalized ratio values and sufficiency of two different local hemostatic measures in anticoagulated patients. Eur J Dent 2014;8(4):475-480 